\title{
"SELECTIVE INCORPORATION" IN THE FOURTEENTH AMENDMENT
}

\author{
LOUIS HENKIN†
}

DuRING recent Terms, four justices of the Supreme Court of the United States espoused a doctrine of "selective incorporation"; the fourteenth amendment incorporates specific provisions of the Bill of Rights, and those that are "absorbed" at all are incorporated whole and intact, providing protections against the states exactly congruent with those against the federal government. ${ }^{1}$ Of the other justices presently sitting, one has rejected this view, while the others have not felt compelled to address themselves directly to it. ${ }^{2}$ Students of the Court have been strangely silent about this interpretation of the Constitution, perhaps holding breath while it hovers on the brink of obtaining a majority in a changing Court. Since this doctrine would be a major tenet of constitutional jurisprudence, relevant to the resolution of issues which come regularly before the Court, it seems appropriate to draw attention to it, to examine its credentials, to consider its implications.

Before examining the doctrine of selective incorporation, it may help to recall its background. From the beginning, the Court has rejected the claim that the fourteenth amendment subjected the states to all the limitations in the Bill of Rights, which were originally written to govern the federal government only. ${ }^{3}$ In 1947, in Adamson v. California, ${ }^{4}$ three Justices joined Mr. Justice

$\dagger$ Hamilton Fish Professor of International Law and Diplomacy, Columbia University School of Law.

1. This view was expounded by Mr. Justice Brennan, joined by the Chief Justice and Justices Black and Douglas, in an opinion in Ohio ex rel. Eaton v. Price, 364 U.S. 263, 27476 (1960), and again in Justice Brennan's dissenting opinion in Cohen v. Hurley, 336 U.S. 117, 154 (1961). Compare Douglas, J., concurring in Gideon v. Wainwright, 372 U.S. 335, 345-47 (1963). It may have been suggested earlier by Mr. Justice Black in his dissent in Adamson v. California, 332 U.S. 46, 85-86 (1947), but to him and to Justice Douglas this was a compromise, less desirable than complete incorporation of the Bill of Rights in the fourteenth amendment. See text accompanying note 4 infra. We shall call the latter the Black doctrine as distinguished from the Brennan doctrine which is the subject of these pages.

2. During the last term of Court, eight Justices held that the standards for permissible search and seizure were the same for the states as for the federal government. Ker v. California, 374 U.S. 23 (1963). A unanimous Court also held in effect that the states must provide counsel to the indigent in criminal cases, as is required of the federal government. Gideon v. Wainwright, 372 U.S. 335 (1963). In both cases the opinion of the Court reached the result while skirting the doctrine of incorporation. Mr. Justice Harlan's concurrence in the latter case and his dissent in the former indicate that he definitely rejects incorporation. See also Justice Harlan's concurrence in Lanza v. New York, 370 U.S. 139, 147 (1962), and note 38 infra.

3. E.g., in Hurtado v. California, 110 U.S. 516 (1884); Twining v. New Jersey, 211 U.S. 78 (1908). The leading contemporary cases are Palko v. Connecticut, 302 U.S. 319 (1937), and Adamson v. California, 332 U.S. 46 (1947). Mr. Justice Frankfurter has been the leading contemporary spokesman for the traditional interpretation of due process, for example in his concurring opinion in Adamson, supra at 59-68.

4. 332 U.S. 46 (1947). 
Black in a strong bid to overrule the accepted view and hold that the fourteenth amendment did apply to the states the whole of the Bill of Rights. Of the four dissenters in Adamson, Justices Black and Douglas remain on the Court and have maintained their views, but no others have seen fit to join them.

In rejecting the suggestion that section one of the fourteenth amendment, or any of its clauses, made the entire Bill of Rights applicable to the states, the Supreme Court did not hold that the amendment afforded no similar protections at all. The Court has developed "substantive due process," imposing limitations on the states which include some similar to the prohibitions in the first and fourth amendments. The Court has also found in the due process clause "procedural due process": this requires of the states those procedures which, in Mr. Justice Cardozo's phrases, are "so rooted in the traditions and conscience of our people as to be ranked as fundamental," which are "of the very essence of a scheme of ordered liberty"; it forbids to the states that which "is repugnant to the conscience of mankind." 6 Procedure by procedure, case by case, the Court has decided whether particular actions of the state did or did not conform to "ordered liberty," to due process of law. Recent years have seen the Court increase steadily the procedural content of the due process clause and its limitations on the states. ${ }^{7}$ In other cases, dissenting Justices would have had the Court increase still further the requirements of procedural due process, sometimes to make them coterminous with limitations imposed by the Bill of Rights on the federal government. ${ }^{8}$

Selective incorporation would apply to the states the substantive provisions of the first and fourth amendments, imposing the same limitations that these amendments place on the federal government. ${ }^{9}$ The principal target of the proponents of incorporation has been criminal procedure and the ordered liberty approach of the Adamson case. If the due process clause forbids only that which violates "ordered liberty," every challenged procedure must make its own way into the conscience of mankind as the Court reads that conscience. In each case it is necessary to decide whether what was done is so gross as to

5. Justice Douglas reasserted his Adanson view last term, expressing the hope that it may yet obtain a majority. See his concurring opinion in Gideon v. Wainwright, 372 U.S. 335, 345 (1963). In Ohio ext rel. Eaton v. Price, 364 U.S. 263, 275 (1960), Mr. Justice Brennan and the Chief Justice indicated that they "have neither accepted nor rejected that view."

6. Snyder v. Massachusetts, 291 U.S. 97, 105 (1934); Palko v. Connecticut, 302 U.S. 319,325 (1938); id. at 323.

7. See Ker v. California, 374 U.S. 23 (1963); Gideon v. Wainwright, 372 U.S. 335 (1963). And see, Rochin v. California, 342 U.S. 165 (1952); Thompson v. Louisville, 362 U.S. 199 (1960); Robinson v. California, 370 U.S. 660 (1962).

8. In addition to Adamson v. California, 332 U.S. 46 (1947), and Cohen v. Hurley, 366 U.S. 117 (1961), see, e.g., Louisiana ex rel. Francis v. Resweber, 329 U.S. 459 (1947); cf. Frank v. Maryland, 359 U.S. 360 (1959), and Ohio ex rel. Eaton v. Price, 364 U.S. 263 (1960). And see Mapp v. Ohio, 367 U.S. 643 (1961), and Gideon v. Wainwright, 372 U.S. 335 (1963), which overruled earlier cases setting lower standards for the states.

9. See text accompanying note 37 infra. 
be unfair or uncivilized. Even where a safeguard is found to be required by due process, it may not be as extensive as the procedural safeguards required of the federal government by the appropriate, specific provision of the Bill of Rights. The doctrine of selective incorporation might make it possible to increase the procedural protections of the due process clause in substantial leaps. Under this doctrine, the Court apparently would not look at the procedure followed by a state in a particular case to determine whether it shocks the conscience of mankind. Rather it would hold to the light of due process the various provisions of the Bill of Rights. ${ }^{10}$ If a particular provision is incorporated within the due process clause, that provision applies to the states to the same extent and in the same ways as it does. to the federal government. Thus, not only the freedoms of the first amendment and the right to be secure from unreasonable search and seizure, but also the right to counsel, the provision against cruel and unusual punishment, even the freedom from double jeopardy and the privilege against self-incrimination, might apply to the states in their full, federal measure.

"Selective incorporation" may represent a compromise with Mr. Justice Black's view of incorporation of the whole Bill of Rights. Perhaps, indeed, it is an effort to achieve, more acceptably, substantially what Mr. Justice Black's position in Adamson sought to achieve and failed to achieve. It might be more acceptable in that it does not depend on Justice Black's views of the history of the amendment and the intention of its draftsmen, views which historians have challenged. ${ }^{11}$ Selective incorporation does not so clearly require overruling the consistent; often reaffirmed, and almost unanimous jurisprudence of the Court for nearly a hundred years. And since it does not involve automatic absorption of the whole of the Bill of Rights, selective incorporation permits the abandonment, as regards the states, of one or more provisions of the Bill of Rights that seem less important and would be too onerous-say, that dated provision in the seventh amendment requiring a jury trial in civil cases where the value in controversy exceeds twenty dollars. For the rest, selective incorporation could apply to the states all the "important" provisions of the Bill of Rights in their full and growing vigor. Moreover, unlike Mr. Justice Black's position, this view, presumably, does not preclude the Court from finding in the due process clause additional protections not found in any of the specifics of the Bill of Rights. ${ }^{12}$

10. Presumably, if the state action complained of does not correspond to any rubric in the Bill of Rights, Mr. Justice Brennan would apply the test of ordered liberty directly, finding in it some limitations beyond the specifics of the Bill of Rights. In this respect he would join Justices Murphy and Rutledge. Conpare their dissenting opinion in Adamson v. California, 332 U.S. 46, 124, with that of Justices Black and Douglas, id. at 68.

11. See Fairman, Does the Fourteenth Anendment Incorporate the Bill of Rights?, 2 Stan. L. Rev. 5 (1949); and Morrison, Does the Fourteenth Amendment Include the Bill of Rights?, id. at 140.

12. See note 10 supra. Since Adanson, Justices Black and Douglas, too, have been willing to find state violations of due process that do not readily correspond to any specific provision in the Bill of Rights. See, e.g., In re Oliver, 333 U.S. 257 (1948); Leland v. Oregon, 343 U.S. 790, 802 (1948) (Frankfurter and Black, JJ., dissenting); United States 
In addition to its promise to raise the standards of individual protection against the states to the higher, federal level, the proposed doctrine has other claims. It is difficult, says Justice Brennan, the chief proponent, to "follow the logic which applies [to the states] a particular specific [of the Bill of Rights] for' some purposes and denies its application for others," or to perceive what warrant there is for applying to the states only a "watered-down; subjective version of the individual guarantees of the Bill of Rights. . . ."13 The suggested doctrine also appears to avoid the impression of personal, ad hoc adjudication by every court which attempts to apply the vague contents and contours of "ordered liberty" to every different case that comes before it: Finally, in respects here relevant, the citizen does not distinguish between state and federal government $;^{14}$ he may not understand why the same standards should not apply. If he reads his Constitution, most of the Bill of Rights is addressed at large, not expressly to the federal government alone; he may not understand why he should not enjoy against the states what the Bill of Rights says is his right. Similar standards for state and nation, moreover, would simplify constitutional jurisprudence, the administration of justice, and cooperation between state and federal agencies.

The thesis, and its consequences, are appealing. That it has not, to date, obtained a majority may reflect its difficulties. Principally, perhaps, it is difficult to find it in the Constitution, as it was written or as it has developed. Even leaving aside considerations of federalism that might militate against such interpretation of the amendment, the burden in logic and in law, surely, is not on those who would claim that the states are subject to lesser limitations than were imposed on the federal government. Initially, at least, the burden is on those who would invalidate action of a state to find in the Constitution some relevant limitation. And the burden of showing that specifics of the Bill of Rights, admittedly written only as limitations on the federal government, are at all relevant to the powers of the states, and in what way, is on those who would assert such relevance. Selective incorporation finds no support in the language of the amendment, or in the history of its adoption. Indeed it is more difficult to justify than Justice Black's position that the Bill of Rights was wholly incorporated. There is some evidence that some persons associated with the adoption of the amendment contemplated that it might apply the Bill of Rights to the states. ${ }^{15}$ There is no evidence, and it is difficult cx rel. Smith v. Baldi, 344 U.S. 561, 570 (1953) (Frankfurter, Black and Douglas, JJ., dissenting) ; Alcorta v. Texas, 355 U.S. 28 (1957) ; Caritatio v. California, 357 U.S. 549, 552 (1958) (dissenting opinion joined by Douglas, J.) ; Scull v. Virginia ex rel. Comm. on Land Reform \& Racial Activities, 359 U.S. 344 (1959); Thompson v. Louisville, 362 U.S. 199 (1960).

13. Cohen v. Hurley, 366 U.S. 117, 158 (1961); see Ohio ex rel. Eaton v. Price, 364 U.S. 263, 275 (1960). Justice Brennan argues also that the First and Fourth Amendments have been absorbed and that there is no reason to consider the rights secured by some later amendments less important. See note 47 infra.

14. Cf. Black, J., dissenting in Bartkus v. Illinois, 359 U.S. 121, 155 (1959).

15. See Mr. Justice Black's dissenting opinion and Appendix in Adamson v. California, 332 U.S. $46,68,92$ (1947). 
to conceive, that anyone thought or intended that the amendment should impose on the states a selective incorporation. In the absence of any special intention revealed in the history of the amendment, we have only the language to look to. It is conceivable, again, that the phrase "privileges and immunities of citizens of the United States" might include a reference to the whole Bill of Rights. ${ }^{16}$ Surely there is no basis for finding that some "specifics" of the Bill of Rights are, while others are not, privileges and immunities of national citizenship. Even the phrase "due process of law" might conceivably be a short-hand expression for the whole Bill of Rights. It is hardly possible to see in that phrase some purpose to select some specifics of the Bill of Rights and an insistence that they be selected whole.

In fact, it should be clear, the Court has not read "due process of law" as a short-hand way of referring to specifics of the Bill of Rights. (It could hardly have so read a clause which restates, identically, only one single provision of only one of the early amendments.) To find in that phrase any limitations at all it had to give meaning and content to the phrase "due process of law." It found protection for "liberty," including the liberties mentioned in the first and fourth amendments, in notions of "substantive due process." Of this, we treat separately later. In regard to procedural due process, the Court held that the "process" that is "due"-say, in criminal proceedings- is what is required by the conscience of mankind. That is the essential link between the constitutional language and purport and all the procedural limitations which the Court applies to the states under this provision. So far as here relevant, then, all that is required of the states is that which is due because it is "fundamental," because its denial would shock the conscience of mankind. There is no relation-historical, linguistic or logical-between that standard and the specific provisions, or any specific provision, of the Bill of Rights. ${ }^{17}$ At bottom, it is difficult even to ask meaningfully whether a specific of the Bill of Rights is incorporated in ordered liberty. That a particular procedure or action is required of, or forbidden to, the federal government by a provision of the Bill of Rights is some evidence that it may be required, or forbidden, by the conscience of mankind. But this indirect relevance of the Bill of Rights to determine the content of "due process of law" cannot support the view that any provision of the Bill of Rights, in its total federal import, is either all in, or all out of, this standard of ordered liberty. Some specifics of the Bill of Rights, in all their manifestations, may indeed be "process" which is required by the conscience of mankind; others may not. Some elements or aspects of a specific may be required by the conscience of mankind; others may not.

16. This was argued, and rejected, in Twining v. New Jersey, 211 U.S. 78, 93-99 (1908). Mr. Justice Black does not rely on the privileges and immunities clause alone: perhaps he recognizes the difficulty, inter alia, that the provisions of the Bill of Rights are not rights of citizens only but are enjoyed by non-citizens as well. Similarly, any protections against the states which the privileges and immunities clause would afford would, by its terms, be enjoyed only by citizens.

17. See note 20 and text accompanying note 23 infra. 
So far as it would incorporate, in procedural due process, procedural provisions of the Bill of Rights, then, the proposed doctrine does not appear to be one that can be reasonably arrived at from the language and history of the fourteenth amendment, or from its development in the constitutional jurisprundence of the Supreme Court. It does find its roots in language used by the Supreme Court in some of the cases. Where a claimant urged that the state had denied him due process-say by denying him a right to be represented by counsel in a criminal case-the issue properly raised was whether the right to counsel, in the circumstances, was a fundamental right, essential to ordered liberty. That the claimant would have counsel as of right in a comparable federal proceeding would be, we have said, some evidence that it may be fundamental. But counsel, as well as the Justices, sometimes framed the issue as whether "the right to counsel" was "incorporated," "absorbed," or "applied" to the states by the fourteenth amendment. If the queston is whether a right contained in the Bill of Rights is "incorporated," one may argue that the right "incorporated," as if by reference, must be the same right with the same meaning and the same scope.

In order to determine whether a particular procedural safeguard, in a particular case or in all cases, is "due" process, i.e., is required by the conscience of mankind, it does not appear apt or relevant to ask whether a particular provision of the Bill of Rights is "incorporated" in due process. In any event, in regard to standards of criminal procedure at least, no case has said that a specific provision in the Bill of Rights, or a federal standard, is being "incorporated."18 A right of counsel, one might say, was incorporated in the fourteenth amendment, but not necessarily the same right of counsel given in the fifth amendment. ${ }^{19}$ What is clear, too, is that the Court could-and did-justify any such "incorporation" only by finding it in the concept of ordered liberty that is due process. ${ }^{20}$ Incorporation then does not, and cannot, avoid reference to the uncertain, debatable, changeable touchstone of ordered liberty. And incorporation, by reference to ordered liberty, cannot claim that specific procedural provisions in the Bill of Rights are incorporated "whole." Ordered liberty, indeed, may for some safeguards require exactly what is re-

18. The Court may have said that a specific provision of the Bill of Rights-say, the privilege against self-incrimination—was not incorporated. Twining v. New Jersey, 211 U.S. 78 (1908). That, too, was careless and unnecessary. The issue before the Court in that case was only whether what the state there did-permitting the prosecution to comment on the defendant's failure to take the stand-was consistent with fairness and ordered liberty. See text accompanying note 26 infra. In any event, that a particular provision of the Bill of Rights may not be incorporated at all, does not imply that other provisions, which may be incorporated, must be incorporated whole.

19. Cf. Powell v. Alabama, 287 U.S. 45 (1932) ; compare Betts v. Brady, 316 U.S. 455 (1942), overruled, Gideon v. Wainwright, 372 U.S. 335 (1963).

20. As to the rights "incorporated," the Court in Treining said: "If this is so, it is not because those rights are enumerated in the first eight amendments, but because they are of such a nature that they are included in the conception of due process of law." Twining $v$. New Jersey, 211 U.S. 78, 99 (1908). See, too, Mr. Justice Cardozo in Palko v. Connecticut, 302 U.S. 319, 327 (1937). See text accompanying note 23 infra. 
quired by the Bill of Rights. But it can as well require less, or more. Nothing in that concept suggests that if it includes some procedure akin to one in the Bill of Rights, it must be of exactly the same size, shape, scope as the federal protection.

It has sometimes been claimed that this doctrine of selective incorporation derives from Justice Cardozo's opinion for the Court in Palko v. Connecticut. ${ }^{21}$ We shall deal later with the dictum of Mr. Justice Cardozo about "absorption" within the Fourteenth Amendment of basic substantive freedoms like those in the First Amendment. ${ }^{22}$ But in regard to the criminal procedures required in the later amendments, for which the doctrine is now invoked, Palko was not applying a doctrine of incorporation as distinguished from a touchstone of "ordered liberty." It was in this case, involving criminal procedure, that Justice Cardozo coined "ordered liberty." Nor did the Court ask whether some specific of the Bill of Rights was incorporated in "ordered liberty." In fact, in setting forth ordered liberty as the meaning of due process, Justice Cardozo said that whether procedure claimed to be required of a state would have been required of the federal government by a specific provision in the Bill of Rights was not the question. Speaking, with apparent approval, of Pozvell v. Alabama, he said:

The decision did not turn upon the fact that the benefit of counsel would have been guaranteed to the defendants by the provisions of the Sixth Amendment if they had been prosecuted in a federal court. The decision turned upon the fact that in the particular situation laid before us in the evidence the benefit of counsel was essential to the substance of a hearing. ${ }^{23}$

Most important, Mr. Justice Cardozo quite clearly rejected the principal focus of the proposed doctrine-that specifics must be incorporated whole. In that case the Court held that it was not a denial of due process for the State of Connecticut to appeal error in Palko's first trial and upon reversal to bring him to trial again and convict him. Since the Court assumed that this would be forbidden to the federal government as "double jeopardy," it is sometimes said that the Court held that the provision against double jeopardy in the fifth amendment was not incorporated into the fourteenth amendment. In fact, the Court held, and could have held, nothing of the kind. It held nothing with regard to the fifth amendment; it held only that what Connecticut did was not a violation of due process. But if it be deemed to have held anything about the incorporation of the provision against double jeopardy, it held only that.federal double jeopardy in all its aspects and reach was not incorporated

21. 302 U.S. 319 (1937). See the opinions of Mr. Justice Brennan in the cases cited in note 1 supra. See also Mr. Justice Black's dissent in Adamson v. California, 332 U.S. at 46, 85-86 (1947). "If the choice must be between the selective process of the Palko decision applying some of the Bill of Rights to the States, or theTreining rule applying none of them, I would choose the Palko selective process." Id. at 89. Mr. Justice Black, of course, did not feel limited to this choice.

22. Palko v. Connecticut, 302 U.S. 319,326 , quoted at note 37 infra.

23. Id. at 327, referring to Powell v. Alabama, 287 U.S. 45 (1932); see also 302 U.S. at $324-25$. 
in due process. It expressly reserved the possibility that some parts of the federal protection against double jeopardy might-if you will-be incorporated in due process: "What the answer would have to be if the state were permitted after a trial free from error to try the accused over again or to bring another case against him, we have no occasion to consider." 24 One could hardly doubt, indeed, that such "true" double jeopardy would have been held by Justice Cardozo, and that Court, to be a violation of due process. ${ }^{25}$ If so, Palko clearly does not support a doctrine that procedural "specifics" which are incorporated at all must be incorporated whole. In fact, since "hard core" double jeopardy would almost certainly be "incorporated," once the Court so held, the doctrine of selective incorporation would require the Court to apply the double jeopardy provision whole, and to overrule Palko!

The Court has also consistently negated the doctrine of "incorporation whole" in the cases involving the so-called privilege against self-incrimination. It is sometimes said-even by the Justices-that the Court has refused to find that the fourteenth amendment incorporated the fifth amendment's provision that no person shall be compelled to be a witness against himself. In fact, the Court held only that the state did not violate due process if it permitted the prosecution to comment on the failure of Twining, or Adamson, to take the stand. ${ }^{26}$ If it held that to this extent the privilege of the fifth amendment was not "incorporated," so be it. At the same time, and with full awareness, the Court has-if one would speak in terms of incorporation of specifics-repeatedly held applicable to the states that part of the privilege not to be compelled to testify against oneself which bars the use of coerced confessions. ${ }^{27}$ These two strands of self-incrimination cases have existed side by side, and have been applied consistently by the Court, including many of the Justices who sat in Palko. There was never any suggestion that these cases were inconsistent with each other, or with some constitutional doctrine of selective incorporation. ${ }^{28}$

24. Id. at 328. Earlier the Court emphasized that it was talking only about the particular kind of double jeopardy in the case: "Is double jeopardy in such circumstances, if double jeopardy it must be called, a denial of due process forbidden to the states?" Id. at 323. And later: "Is that kind of double jeopardy to which the statute has subjected him a hardship so acute and so shocking that our polity will not endure it ?" $I d$. at 328 .

25. Compare Hoag v. New Jersey, 356 U.S. 464, $468-69$ (1958); United States v. Furlong, 18 U.S. (5 Wheat.) 184, 197 (1820).

26. Twining v. New Jersey, 211 U.S. 78 (1908); Adamson v. California, 332 U.S. 46 (1947). See note 18 supra. Both Mr. Justice Brennan and Mr. Justice Black recognized the limits of the holding, urging that Twining did not conclude the case before the Court, in their dissents in Cohen v. Hurley, 366 U.S. 117, 134-35 n.10, 159 (1961). Mr. Justice. Black had also recognized earlier that in these self-incrimination cases the Court was negating any notion of total incorporation, applying to the states part of the federal privilege but not all of it. See his dissent in Adanison, 332 U.S. at 86.

27. Brown v. Mississippi, 297 U.S. 278 (1936) ; Chambers v. Florida, 309 U.S. 227 (1940).

28. These self-incrimination and double jeopardy cases, of course, reveal the corollary of the proposed doctrine. Selective incorporation means that the Fourteenth Amendment takes all of a federal provision, or it takes none of it. The:Court could not, then, keep both 
These difficulties suggest that the proposed doctrine would seek possible additional protections for the individual on the wings of inadequate analysis, in the face of the language and history of the fourteenth amendment, and almost a hundred years of constitutional jurisprudence. One may well ask, moreover, what is gained. In fact, selective incorporation cannot avoid the difficulties of the traditional doctrine. Try as one might to avoid the phrase, "ordered liberty" or something much like it remains as the principle of selection, to determine which specifics are "incorporated," and which are not. (Some such standard is applied, too, where there is a challenge to a procedure which does not correspond to any federal specific.) That judgment of selection is as likely to be "subjective" as is the application of the traditional standard. And if the traditional approach sometimes applies a "watered-down" version of some federal procedural specific, one can as well challenge selective incorporation as a watered-down version of incorporation of the entire Bill of Rights.

Most important, perhaps, accepting the need or the desirability of increasing constitutional protections against the states, one may yet ask whether this doctrine is really necessary. If the federal standard is indeed the goal in some instances, the Court can, without any difficult new doctrine, find the federal standard to be required by ordered liberty or by other elements in the Court's jurisprudence. That is now the case with the right to counsel. ${ }^{29}$ The Court has also found it possible to justify identical standards in regard to exclusion of the fruits of unreasonable search and seizure, not from any notion of total incorporation, but because of convenience in administration and in federal-state cooperation in the enforcement of criminal law..$^{30}$ Federalism and stare decisis apart, without any new doctrine the flexibility and vitality of the concept of ordered liberty ${ }^{31}$ would permit the extension today to the states of the heart

Adamson and the coerced confession cases, both Palko and a rule against "hard-core" double jeopardy. Overruling Adamson and Palko, even on their limited facts, may indeed be what the Brennan doctrine intends. But this all-or-nothing doctrine could, with equal logic, lead to the opposite conclusion. If some part of a "specific" is not included in due process, none of it can be; or, since whether a provision is to be incorporated must still depend on its inclusion in "ordered liberty," if a federal specific includes elements which are shocking and elements which are not, it may be as reasonable to exclude the provision from the fourteenth amendment as to include it. Thus, the Court, having long ago decided Twining and Palko, might be held to have decided that the whole federal privilege against self-incrimination, and the whole rule against double jeopardy, are excluded from the Fourteenth Amendment. Repeated trials and coerced confessions, then, should not be barred to the states either. And new applications involving self-incrimination or double jeopardy should also be permitted although these may, in fact, shock the conscience.

29. Gideon v. Wainwright, 372 U.S. 335 (1963).

30. Ker v. California, 374 U.S. 23 (1963) ; cf. Mapp v. Ohio, 367 U.S. 643 (1961). And, as the Ker case shows, getting the federal standard does not assure that the result will be different; a majority of the Court found that it was not violated.

Security against unreasonable search and seizure is, in the first instance, a substantive right, part of substantive due process. See infra note 44 and accompanying text.

31. See, e.g., Mr. Justice Brandeis, dissenting, in Olmstead v. United States, 277 U.S. 438, 472 (1928) ; compare his dissent in United States v. Moreland, 258 U.S. 433, 451 (1922). See Mr. Justice Frankfurter concurring in Malinski v. New York, 324 U.S. 401, 414 (1945), 
of concepts against double jeopardy, perhaps even against self-incrimination -the only safeguards now apparently in issue-without necessarily saddling all the states with what may be peripheral survivals or accretions in the Bill of Rights. ${ }^{32}$ Of course, if the Justices are not to be imposing their own notions of what is desirable procedure, they can only find these new protections in the fourteenth amendment if they are satisfied that they are indeed required by some impersonal, objective, determinable (if difficult to determine) standard of community conscience. But a similar reference to some similar standard, we have said, could not be avoided if the Court asked anew, for example, "whether the privilege against self-incrimination is incorporated." There is no constitutional language, no established doctrine, no old case, that can be invoked to avoid the inevitable question of ordered liberty.

There is indeed a kind of inversion about attempting today to increase the content of procedural due process vis-à-vis the states through wholesale incorporation of complete provisions of the Bill of Rights. For in regard to the federal government the Court has also been extending constitutional liberties and protections. It has done so in part by recognizing distinct content in the due process clause of the fifth amendment and applying notions of fairness and ordered liberty there. ${ }^{33} \mathrm{It}$ has done so even more by developing the flexible standards of some of the provisions- "unreasonable" search and seizure, "cruel and unusual" punishment, even "double jeopardy."34 The Court, surely, is

and in Joint Anti-Fascist Refugee Comm. v. McGrath, 341 U.S. 123, 162-63 (1951) ; and see Hurtado v. California, 110 U.S. 516, 530 (1884).

32. If selective incorporation accepts that some specifics-like the twenty-dollar rule in the seventh amendment-are outdated, one might leave open the possibility that some specific provision retaining vitality may have accumulated insignificances or anachronisms that should not be imposed on the states.

In fact the practice upheld in Palko is rare and that in Adanson if less rare may not be shocking, or even important. But even if the Court should conclude that, on their facts too, cases like $P a l k o$ and $A d a m s o n$ now represent an older, less sensitive conscience, it does not require any difficult, novel doctrine to justify their re-examination. It would be easier by far to overrule a case than to construct a new jurisprudence for the fourteenth amendment. In fact, of course, older due process cases need not be overruled as erroneously decided; traditional jurisprudence recognizes that due process is a vital concept, its requirements growing with increased enlightenment. See cases cited note 31 stpra. In regard to Adamson, in particular, one can also recognize that the Court there, as in Treining, held only that the particular state practice in question did not violate ordered liberty; the Court has not really considered whether the process due today permits other forms of compelling a person to give witness against himself. See note 26 supra.

33. See, c.g., Crain v. United States, 162 U.S. 625, 645 (1896) ; Japanese Immigrant case, 189 U.S. 86, 100-01 (1903) ; Morgan v. United States, 304 U.S. 1, 18-19 (1938); Wong Tang Sung v. McGrath, 339 U.S. 33, 50 (1950) ; cf. Hannah v. Larche, 363 U.S. 420 (1960). The invocation of due process against the federal government has become less frequent as the Court began to expand the specifics, note 34 infra, and to require even higher standards under its supervisory powers over federal courts and federal administration of justice. McNabb v. United States, 318 U.S. 332 (1943) ; Rea v. United States, 350 U.S. 214 (1956); Mallory v. United States, 354 U.S. 49 (1957).

34. See, e.g., Chapman v. United States, 365 U.S. 610 (1961) ; Trop v. Dulles, 356 U.S. 86 (1958); United States v. Green, 355 U.S. 184 (1957) ; Fong Foo v. United States, 369 U.S. 141 (1962) ; see also United States v. Lovett, 328 U.S. 303 (1946). 
aware that though it is ostensibly applying a "specific," the specific is not very specific; and in seeking a standard for developing these and other ambiguities the Court has inevitably applied contemporary notions of fairness-not very different from "ordered liberty." Sometimes, it seems, the Court has stretched quite far the language of one of the specifics to achieve in effect what it thought required by new communal enlightenment. One may wonder, then, whether in regard to both state and federal governments, the Court might not better look less to the procedural specifics of the Bill of Rights and exploit rather the more flexible notion of due process in both the fifth and fourteenth amendments to achieve identical and contemporary standards of liberty under ordered government. To Mr. Justice Black this approach may still be abhorrent because it leaves the courts at large with too much discretion. ${ }^{35}$ Most of the Justices, one might guess, would not find this discretion distressingly larger than is in play when the Court develops the mentioned ambiguities of the Bill of Rights, or applies the due process clause of the Fifth Amendment, or decrees notions of propriety under the Court's supervisory powers, where there is no applicable specific. ${ }^{36}$

\section{Substantive Due Process and the Substantive Anendments}

Palko v. Connecticut, it seems clear, is not authority for any general doctrine that specifics of the Bill of Rights are incorporated into the Fourteenth Amendment. It is surely not authority-indeed it negates-a doctrine that insists that any federal specific which is at all reflected in "due process" must be incorporated whole. Neither Palko nor any other case, nor independent inquiry, has suggested any acceptable basis for incorporating whole federal specifics in the procedural amendments. But Cardozo's dictum in Palko may suggest incorporation, possibly incorporation whole, of "the privileges and immunities that have been taken over from the earlier articles of the federal bill of rights and brought within the fourteenth amendment by a process of absorption." 37 For these important substantive rights-the freedom of speech, press and religion, separation of church and state, privacy against unreasonable search and seizure-protection against encroachment by the states has also been found in the due process clause, in "substantive due process." That these freedoms are protected against the states to exactly the same extent as against federal abridgment has been asserted, and questioned..$^{38} \mathrm{I}$ venture to

35. See, e.g., his dissent in Adamson v. California, 332 U.S. 46, 90-92 (1947).

36. For examples of the latter, see cases cited supra note 33.

37. 302 U.S. at 326. (Emphasis added). Justice Cardozo goes on to speak in particular of the importance of "freedom of thought, and speech." Id. at 326-27. See also note 46 infra.

38. See Beauharnais v. Illinois, 343 U.S. 250, 288 (1952) (Jackson, J. dissenting) (questioning the view of the other dissent that the first amendment is incorporated in the fourteenth); Roth v. United States, 354, U.S. 476, 505-06 (1957) (Harlan, J. separate opinion) (dangers of a uniform standard as to pornography under the First Amendment applied to the state). The opinions of the Court may have applied the same substantive standard as would apply to the federal government under the Bill of Rights, but have avoided explicit language of incorporation. See Cohen v. Hurley, 366 U.S. 117, 156 (1961) (Brennan, J., 
suggest that as to these provisions-the origin and perhaps a principal motivation for "selective incorporation"-one might arrive where that doctrine would take us, though by another path.

Substantive due process in concept and in its development is, of course, quite different from "procedural due process," although the Court has found them both in the same clause. Due process of law in the original Bill of Rights, while its total impact is less than clear, surely had procedural connotations. The same phrase was probably designed to impose some procedural limitations on the states when it was written into the fourteenth amendment. To determine the scope of these safeguards the Court interpreted the words "due process," holding that the process that is due is that which conforms to accepted notions of "dueness," to the demands of civilized conscience.

"Substantive due process," on the other hand, may be wholly a judicial creation. It was first found in the fifth amendment in the Dred Scott case. ${ }^{39}$ However, when "due process of law" appeared in the fourteenth amendment, it is far from agreed that it intended substantive limitations on what state legislatures might do. Substantive due process, as is well known, found its origin and its wild and questionable growth in regard to economic regulation; only comparatively recently has it begun to protect political and civil liberties. In regard to the latter, when the Court decided, say, that freedom of speech enjoyed protection from state encroachment, it was asserting that the "liberty" of which a person may not be deprived includes the freedom of speech. Liberty, it later held, included other freedoms, indeed "the full range of conduct which the individual is free to pursue." 40 Surely, the Court has found, it included those liberties whose significance was expressly honored in the first and fourth amendments.

One may say, then, that the liberties mentioned in the Bill of Rights were, in this sense, "incorporated" or "absorbed" in the "liberty" protected by the fourteenth amendment. ${ }^{41}$ It remained to be determined what is the standard of protection accorded to these liberties. The scope of the protection has indeed been found in the phrase "due process," but here it means something different from what it means as procedural due process. The standard of substantive due process is not "conscience" or "fairness" as in the procedural cases. Substantive due process, we know, has suggested to the modern Court

dissenting). See also note 47 infra. Compare, e.g., the Court's opinion in Lanza v. New York, 370 U.S. 139, 142 (1962), with Justice Harlan's concurrence, 370 U.S. at 147.

39. Scott v. Sandford, 60 U.S. (19 How.) 393 (1856).

40. Bolling v. Sharpe, 347 U.S. 497,499 (1954).

41. See text accompanying note 37 supra. There is no problem of selection here; all substantive rights, even those perhaps outdated ones in the second and third amendments. are liberties entitled to some protection. The Court has apparently also treated breach by the states in the separation of church and state, or state establishment of religion, as deprivations of "liberty" which affected individuals have standing to vindicate. E.g., Engel v. Vitale, 370 U.S. 421 (1962) ; cf. McGowan v. Maryland, 366 U.S. 420 (1961). See also School District of Abington Township v. Schempp, 374 U.S. 203, 230, 256 (1963) (Brennan, J., concurring). In fact, "non-establishment" and the "wall of separation" figure largely in state cases although no one has suggested that they apply differently to the federal government. 
standards for permissible limitations on property different from those on liberty, and perhaps, too, different standards for limitations on different liberties. In regard to property, or even "economic liberties," the standard has been reduced to mere "reasonableness" of end and means. For "civil liberties" it has meant much greater protection. For property or liberty the standard has reflected developing values, developing attitudes on the relation of government and individual, of order and liberty, applied to the issues of a new day. Except to those who think that the first amendment speaks clearly and absolutely, ${ }^{42}$ however, these same developed values in fact determine the protection accorded by the substantive amendments too-the scope of "respecting an establishment" or "prohibiting the free exercise" of religion, of "abridging" the freedom of speech or of the press, and other ambiguities in the first amendment, as of "the right to be secure" against "unreasonable searches and seizures" in the fourth amendment. To those who see in these amendments flexible standards reflecting respective needs of order and of liberty, it is easy to suggest that there is no reason to assume different values in this regard as concerns the action of the states. ${ }^{43}$ In terms of incorporation, then, one may say that the liberties mentioned in the first and fourth amendments are incorporated in "liberty" in the fourteenth, and that the values of order and liberty which determine the protection accorded against the federal government by the substantive amendments are the same as-are congruent with if not "incorporated" in-substantive "due process of law" applicable to the states.

This suggestion, I emphasize, does not depend merely on linguistic parsing of the different phrases of the due process clause. The point is that if the fourteenth amendment is deemed to afford substantive protection for "liberty," it should surely protect the fundamental and established liberties. And if the Court is creating a standard of protection for these liberties, it may well look to the standards of protection which it has developed for these liberties in regard to the federal government. Surely it may look to those same standards if, as most of the Justices accept, the substantive provisions are "specific" only in identifying the right protected, but not as to elaborating the standard of protection, and the latter must derive from contemporary enlightenment. The fact is that without having explicitly accepted incorporation, the Court never seems to have found in the explicit provisions of the early amendments some standard higher than that to be applied to the states. And even the individual Justices who have insisted that the standard is different have

42. Mr. Justice Black, of course, applies the first amendment to the states as part of his total incorporation of the Bill of Rights, supra note 4 . Alternatively, he might say that the provisions of the first amendment are within the "liberty" protected by the fourteenth amendment. On either basis, Mr. Justice Black might say the "absolute character of the prohibition of the first amendment applies equally to the states.

43. To say that the standard is the same for the states as for the federal government is to suggest the same process of balancing and the same values in the balance. It does not mean that all governmental interests, state or federal, weigh the same. The interest of the United States in advance military censorship in time of war might outweigh the liberty to speak or publish, where a state's concern to prevent libel, by advance censorship, might not. 
not been able to articulate and justify two different standards. ${ }^{44}$ Whether one calls it incorporation or not, identical standards for federal and state governments apparently are established. Incorporating the procedural provisions of the Bill of Rights, on the other hand, would automatically apply to the states provisions of considerable specificity, including the accretions those amendments have acquired in the history of their application to the federal government. Some of these may not fall within the notion of fairness and ordered liberty that is the core of procedural due process. True, in some situations, as in the right to counsel, there may indeed be congruity with federal protection. In others, congruity may not be required by "due process." There seems no occasion to seek it by an artificial process of incorporation.

I am suggesting, then, that the concept of incorporation might be applied to the substantive liberties in the Bill of Rights, though difficult to accept as to the procedural provisions. ${ }^{45}$ (Perhaps, indeed, this distinction accords with the view of Mr. Justice Cardozo, although he apparently saw both kinds of due process as aspects of "ordered liberty.") ${ }^{46}$ Incorporating some provisions of the Bill of Rights and not others needs no special justification. There is, of course, no necessary logical link or relation between the substantive provisions of the early amendments and the procedures later in the Bill of

44. See note 38 sitpra.

45. One need not become enmeshed in difficult distinctions between substance and procedure which elsewhere trouble the law. Substantive due process and procedural due process are phrases of recognized content describing different constitutional limitations on government. And there appears to be no difficulty in separating those provisions of the Bill of Rights which may be called liberties (and deemed incorporated in "liberty" in the fourtenth amendment) from those provisions which prescribe procedures required of the federal government (to which the fourteenth amendment does not speak). Some of the liberties incorporated may raise special procedural problems. The right to be secure from unreasonable search and seizure is an incorporated liberty and the standard of protection applies in the same manner against the states as against federal authorities. Wolf v. Colorado, 338 U.S. 25 (1949) ; Ker v. California, 374 U.S. 23 (1963). If the exclusion of evidence obtained by unreasonable search and seizure is deemed an integral incident of the protection for the liberty, presumably the exclusion of evidence would also be "incorporated." If the exclusion is not a necessary incident of the substantive protection it can be required of the states only if it is an aspect of ordered liberty, or on some other basis. The Court has in fact required exclusion without basing it on incorporation. See note 30 stpra. In regard to the first amendment, too, the Justices have differed as to whether speech or publication subject to regulation (c.g., for obscenity) can be screened in advance or only punished thereafter. Such questions might properly be considered problems in procedural due process with the same standard, presumably, under the fifth and fourteenth amendments. If the propriety of the procedures involved in regulating obscenity were deemed integral to the protection accorded by the first amendment, they would presumably also be "incorporated" in the liberty protected against the states. Compare note 42 supra.

46. At least, in this way one can give literal meaning to his dicta about the "absorption" of the freedoms in the early provisions of the Bill of Rights, and square them with his decision in Palko, his reservation of other double jeopardy cases (see note 24 supra), and his treatment of Powell v. Alabama, 287 U.S. 45 (1932) (see note 23 supra). But Justice Cardozo seems rather to distinguish what is fundamental from what is not, and puts on his higher plan of values, note 47 infra, not only freedom of speech but also the concept of a trial, a fair trial. Palko v. Connecticut, 302 U.S. 319, 326-27 (1937). 
Rights. Nor has the Bill of Rights any necessary logical unity. Its historical unity and significance (which would apply also to the tenth amendment) has no relevance to the fourteenth amendment. What must be remembered is that for the states we start with the fourteenth amendment, not with the Bill of Rights. Unless, with Justice Black, one relies on some special intention of the draftsmen of the amendment, that amendment has no relation to the Bill of Rights as a whole. If one finds in the fourteenth amendment protection for the freedoms in the early amendments, but cannot find in it a requirement for judicial procedures like those in the latter part of the Bill of Rights, it is not because the former amendments "secure more important individual rights." 47 It is rather that one must find some basis for finding in the fourteenth amendment any relation to the Bill of Rights at all. And in the fourteenth amendment, where any incorporation must lie, one may readily find that the "liberty" protected includes the liberties of the early amendments, but it seems difficult to find that the judicial "process" that is "due" relates to the later provisions of the Bill of Rights, incorporates some of them but not all of them, and incorporates them whole. Language aside, the distinction we have suggested appears to accord with the separate and different development and significance of substantive due process from that of procedural due process in the history of the Constitution.

Whether or not one accepts this suggested distinction between the protections afforded to substantive rights and the concept of fairness applied to criminal procedure, one may still conclude that, within the established standard of "ordered liberty," some safeguards contained in provisions of the Bill of Rights might in fact be applied equally to the states, others might not. The suggestion that protections of the Bill of Rights must in all cases be applied exactly to the states, if they be applied at all, is difficult to support as a matter of constitutional language or of the jurisprudence of the Court, or to justify on any other relevant considerations. It creates its own rigidities and runs counter to the direction of growth of the Constitution to embody flexible standards permitting the increase of individual safeguards with the growing enlightenment of contemporary civilization. Even the strongest libertarian instincts do not need such a doctrine to increase protection for the rights of the criminally accused when greater communal enlightenment suggests higher standards to be required of the states as of the federal government.

47. [A] cloud has plàinly been cast on the soundness of Twining and Adamson by our decisions absorbing the first and fourth amendments in the fourteenth. There is no historic or logical reason for supposing that those amendments secure more important individual rights.

Cohen v. Hurley, 366 U.S. 117, 159 (1960) (Brennan, J., dissenting). Under the views suggested in this Note the comparative "importance" of the substantive and the procedural rights is irrelevant. Incorporation of the substantive provisions, it is suggested, is consistent with the language and development of the Constitution; incorporation of the procedures is not.

Mr. Justice Brennan seems to be differing with Justice Cardozo, who in a famous passage in Palko suggests that the freedoms of the first amendment are on "a different plane of social and moral values," freedom of speech, for instance, being "the matrix, the indispensable condition of nearly every other form of freedom." Palko v. Connecticut, 302 U.S. $319,326-27$ (1937). 


\section{THE YALE LAW JOURNAL}

\author{
ROBERT A. Burt \\ JoHN A. KOSKINEN \\ Elliott J. Werss \\ WilliaM C. WHitroRd \\ Note \& Comment \\ Editors
}

\section{Peter L. Strauss \\ Editor-in-Chief \\ Monroe E. Price \\ Executive Editor}

EdWARd L. BarLow

Donald C. Christ

Joseph D. Clayton

Edward R. CoHen

Stephen R. FIELd

Thomas K. Gilhoor

JoHN GrIFFtThs

Paul Grossman
Robert E. CoOper

Steven M. UMIN Article \& Book Review Editors

Roger W. ToMrpins Managing Editor
EARL W. Shapiro
Butsiness Manager
Charles $R$. Halpern

JoHn D. HofraraN Mrchaer J. Horowitz ALAN D. JACOBSON HowaRd J. KasLow RICHARD A. Katzive JoEN L. KRAFT
Rod MCMAHAN Josepe D. MANDEL Daniel Marcus Charles M. Nathan David A. Rahas Owen J. Sloane George P. SmIth JoHN A. Young

\section{CONTRIBUTORS TO THIS ISSUE}

EUgene V. Rostow. B.A. 1933; M.A. 1937; LL.B. 1959, Yale University; Dean of the Law School.

Williaar O. Douglas. B.A. 1920, Whitman College; LL.B. 1925, Columbia University; Associate Justice, United States Supreme Court.

JoHN P. FrANK. B.A. 1938; M.A. 1940; LL.B. 1940, University of Wisconsin; J.S.D. 1947, Yale University.

RALPH K. WINTER, JR. B.A. 1957; LL.B. 1960, Yale University.

Lours Henkrn. B.A. 1937, Yeshiva College; LL.B. 1940, Harvard University; D.H.L. 1963, Yeshiva University.

Hans Von Hentig. Dr. Iur, University of Munich; Visiting Professor, Yale University 1936-37.

MIARC ANCEL. Licencié ès-Lettres; J.S.D.; Doctentr Honoris Cansa, Universities of Geneva and Edinburgh.

JacQues BARzUn. B.A. 1927; Ph.D. 1932, Columbia University. 